\title{
GATA6 wt Allele
}

National Cancer Institute

\section{Source}

National Cancer Institute. GATA6 wt Allele. NCI Thesaurus. Code C104417.

Human GATA6 wild-type allele is located within 18q11-q12 and is approximately $33 \mathrm{~kb}$ in length. This allele, which encodes transcription factor GATA- 6 protein, is involved in regulation of cellular differentiation and organogenesis during development. Mutations in this gene are associated with several congenital defects. 